\title{
LOS PODERES PROBATORIOS DEL JUEZ CIVIL CUBANO. DEBATES IDEOLÓGICOS Y EL NUEVO MODELO PROCESAL ${ }^{1}$
}

\section{THE POWERS OF THE CUBAN CIVIL JUDGE. IDEOLOGICAL DEBATES AND THE NEW PROCEDURAL MODEL}

\section{Luis Alberto Hierro Sánchez}

Licenciado en Derecho por la Universidad de La Habana (2014). Profesor Asistente de Derecho Procesal, Derecho de Obligaciones y Derechos de Contratos de la Facultad de Derecho de la Universidad de La Habana. Juez de la Sala Segunda de lo Civil y lo Administrativo del Tribunal Provincial Popular de La Habana. Miembro de la Sociedad Cubana de Derecho Procesal de la Unión Nacional de Juristas de Cuba y Presidente de su Capítulo Provincial en La Habana. Havana, Cuba. E-mail: hierro@lex.uh.cu (ORCID: https://orcid.org/0000-0002-5023-5647

RESUMEN: Los poderes del juez constituyen un tema recurrente en cualquier agenda de Derecho Procesal, a partir de los debates ideológicos que todavía persisten en la doctrina moderna, fundamentalmente en materia probatoria. La idea de un proceso civil garantista asociada a la inactividad de los jueces se contrapone a la de un juez activo en la dirección procesal y material del litigio. Al caso cubano no le es ajena dicha polémica, ya que la Ley de Procedimiento Civil, Administrativo, Laboral y Económico regula un prototipo de juez con amplios poderes que en la práctica no ha tenido la repercusión necesaria, producto de la influencia española decimonónica; panorama que parece cambiar tras la promulgación de la nueva Constitución de la República y el proceso de reforma legislativo derivado de ella.

PALABRAS CLAVE: Poderes del juez. Ideología. Iniciativa probatoria. Garantismo procesal. Activismo judicial.

\footnotetext{
${ }^{1}$ Artigo recebido em 01/12/2020, sob dispensa de revisão.
} 
ABSTRACT: The powers of the civil judge are a frequent topic in any procedural law agenda, based on the ideological debates that still persist in modern doctrine, essentially in matters of evidence. The idea of a civil guarantee process is associated with the inactivity of the judges, a theory that is opposed to the idea of judicial activism in the procedural and material direction of the conflict. This controversy is not alien to the Cuban case, since the Civil, Administrative, Labor and Economic Procedural Law regulates a prototype of a judge with sufficient powers that in practice have not reached the necessary relevance, as a result of the nineteenth-century Spanish influence; scenario that seems to change after the promulgation of the new Constitution of the Republic and the legislative reform process derived from it.

KEY WORDS: Powers of judges. Ideology. Evidentiary initiative. Procedural guarantees. Judicial activism.

\section{Introducción necesaria}

Desde la perspectiva del Derecho Procesal, la labor de los jueces ha estado presente desde los orígenes de los modelos de enjuiciamiento. Los cinco siglos de proceso inquisitivo en Europa y por derivación en América, perfilan un modelo de juez con amplias facultades ${ }^{2}$, tanto en la conducción del procedimiento, como en los poderes que trascienden al plano material. El Siglo XIX, por su parte, trae consigo "un giro copernicano" en la forma de enjuiciamiento, ya que el movimiento codificador napoleónico sienta las bases para la evolución hacia un escenario procesal diferente, con un modelo de juez en contraposición al prototipo inquisitivo precedente ${ }^{3}$.

La codificación española decimonónica perfila un modelo de juez con poderes limitados, pues prevalece la desconfianza en las atribuciones que los magistrados pudieran asumir en conflictos que tienen como sustento esencial un derecho privativo de las partes. Se visualiza la función de impartir justicia como una actividad estatal, pero limitada, en tanto

\footnotetext{
${ }^{2}$ Ad mayor abundatia vid. Mendoza DíAz, J., Derecho Procesal. Parte General, Ed. Félix Varela, La Habana, 2015, pp. 1-17.

${ }^{3}$ Couture, E., Estudios de Derecho Procesal Civil, Tomo I, Ediar Editores, Buenos Aires, 1948, p. 307.
} 
las partes actúan como dueñas absolutas del contenido de la litis y cualquier posibilidad de intromisión del juez en ese ámbito queda absolutamente vedada.

La historia señala con especial atención la reforma procesal ocurrida en Austria a finales del Siglo XIX, con la promulgación de la Ordenanza Procesal de Franz KLEIN, que introduce un modelo procesal caracterizado por la oralidad, la concentración de actos procesales y las amplias potestades de los jueces en la conducción del proceso. Sin embargo, razones de diferente naturaleza conducen a que el modelo procesal de KLEIN no logre la aceptación y difusión requeridas hasta que, a mediados del siglo XX, las reformas procesales que se gestan en Europa y América Latina lo rescatan como referente para la creación de un nuevo modelo procesal ${ }^{4}$.

En el campo conceptual les corresponde a los grandes maestros del Derecho Procesal italiano el mérito de haber reclamado una posición más activa de los jueces en el proceso civil. Se parte del presupuesto, expuesto por CALAMANDREI, de que en el juicio se decide la aplicación de una norma que encarna la voluntad estatal, razón por la cual al Estado no le pueden ser indiferentes los destinos del proceso y fundamentalmente de quien lo conduce ${ }^{5}$. En este contexto, la promulgación del Código Procesal Civil italiano de 1940 marca un hito trascendental en la conformación del proceso civil actual, ya que comienza a hablarse de litis y proceso como conceptos diferentes y separados, con el objetivo de distinguir los aspectos procesales de los materiales y, en consecuencia, empoderar al juez como director del proceso.

A su turno, los procesos de reforma acaecidos en el contexto iberoamericano desde finales del siglo XX y comienzos del XXI, a pesar de tomar referencia de los Códigos

\footnotetext{
${ }^{4}$ Sobre el legado de Franz KLEIN y su trascendencia para el proceso civil moderno vid. AlCALÁ-ZAMORA Y Castillo, N., "La influencia de Wach y Klein sobre Chiovenda", en Revista de Derecho Procesal, Buenos Aires, 1947, pp. 389 y ss. De fecha reciente vid. también CIPRIANI, F., "Ideología de la función judicial. En el centenario de Klein", en Revista de Instituto Colombiano de Derecho Procesal, Vol. 27, Bogotá, 2001.

${ }^{5}$ En este sentido, el maestro italiano advierte con total tino que "La función del abogado aparece, por el contrario, profundamente cambiada y elevada, cuando en el Estado constitucional, que reivindica para sí la función jurisdiccional como complemento indispensable de la legislativa, se comienza a sentir que el resultado del proceso no es extraño al interés público, ya que en todo proceso se encuentra en juego la aplicación de la ley, es decir, el respeto a la voluntad colectiva. Y esto no sólo en el proceso penal, que se construye hoy totalmente sobre el derecho subjetivo de castigar, que pertenece al Estado, sino también en el proceso civil, en el cual el interés individual de los litigantes aparece cada vez más como el instrumento inconsciente del interés público, que se sirve de la iniciativa privada para reafirmar en los casos controvertidos la voluntad concreta de la ley". Vid. Calamandrei, P., Demasiados abogados, Biblioteca de la Revista de Derecho Privado, Serie AI, Librería de Victoriano Suárez, Madrid, 1926, p. 3.
} 
Procesales Modelos $^{6}$, no han podido evitar el resurgimiento de un pensamiento neoconservador que, bajo el pretexto de un juez autoritario y dictatorial, trata de reducir su papel en el proceso a una expresión mínima. Corriente de pensamiento que, de la mano de Montero Aroca, Cipriani, Monteleone y Alvarado Velloso, condena cualquier forma de activismo judicial, en tanto no considera la intervención del juez en el proceso como una expresión del garantismo consagrado en los textos constitucionales para la protección de los derechos de los justiciables.

Otro grupo de autores sostienen con fuerza la que pudiera denominarse como concepción kleniana del proceso civil, en la que el juzgador se convierte en garante del debido proceso judicial al estar dotado de un conjunto de poderes que le permiten administrar justicia desde el mismo momento en que se echó a andar la maquinaria jurisdiccional. Autores como Berizonce, Taruffo, Morello, Parra Quijano, Barbosa Moreira y PICó I JUNOY defienden la idea del juez como autoridad encargada de dirigir el proceso sin caer en excesos ${ }^{7}$. No pueden identificarse entonces los conceptos de autoridad con autoritarismo, cual libertades ilimitadas que someterían a la justicia al imperio de la discrecionalidad judicial. Se trata de poderes, cual potestades, no de libertades asociadas a la función jurisdiccional.

Por su parte, Cuba no ha estado ajena a este debate y es meritorio señalar el destacado trabajo elaborado por Álvarez TABío, de 1946, titulado "El Juez Activo en el Proceso Civil”, donde reclama para los magistrados un papel más preponderante en la conducción de los procesos ${ }^{8}$. Tampoco puede dejar de mencionarse el Proyecto de Código Procesal Civil de Guillermo Montagú, de 1951, que promueve la idea de un juez con amplios poderes para el impulso y la dirección del proceso, así como la posibilidad de disponer de oficio las medidas necesarias para garantizar la igualdad de las partes, convocarlas en cualquier estado

\footnotetext{
${ }^{6}$ Dichos Códigos Procesales Modelos sirvieron de referente a finales del siglo XX y comienzos del XXI, para la promulgación del Código General del Proceso del Uruguay en 1988, de la Ley de Enjuiciamiento Civil española del 2000, el Código General del Proceso de Colombia de 2012, así como los más recientes Código de Proceso Civil de Brasil y el Código Orgánico General de Procesos del Ecuador, ambos de 2015; y el Código Procesal Civil de Costa Rica de 2016.

${ }^{7}$ Una visión bastante completa del fenómeno ideológico en el proceso civil se encuentra en MONTERO AROCA, J. (Coord.), Proceso Civil e Ideología. Un prefacio, una sentencia, dos cartas y quince ensayos, $2^{\mathrm{a}}$ edición, Ed. Tirant lo Blanch, Valencia, 2011.

${ }^{8}$ ÁlvareZ TABío, F., "El juez activo en el proceso civil", en A.A.V.V., Anuario de la Asociación Nacional de Funcionarios del Poder Judicial, Curso de Conferencias sobre Derecho Procesal, Ed. Lex, La Habana, 1946.
} 
del proceso e interrogarles sobre el objeto de la litis siempre que lo estime oportuno, y ordenar las inspecciones necesarias para el mejor conocimiento de los hechos ${ }^{9}$.

La reforma procesal cubana de los años setenta recibe los efluvios de la teoría del Derecho Socialista soviético e introduce un catálogo de facultades a los jueces. Empero, no ha sido práctica frecuente de los jueces cubanos el uso del abanico de potestades que les franquea la ley. Resulta de conocimiento en el gremio jurídico que ha correspondido al Consejo de Gobierno del Tribunal Supremo Popular (CGTSP), a través de sus Instrucciones ${ }^{10}$, revitalizar dichos poderes, pues su ejercicio ha sido prácticamente nulo. No obstante, en el proceso civil aún persisten los rasgos del proceso escriturado y solo se le concede espacio a la oralidad en los actos judiciales que de manera prospectiva regula la ley. La reforma procesal de 2006 no solo introduce un nuevo proceso -el económico-, sino que trae consigo la implementación de un nuevo modelo procesal que converge, convive y se yuxtapone al proceso civil. Dicha reforma procesal tiene como cimiento la reconfiguración de los principios guías del proceso, con mayor presencia de la oralidad y, consecuentemente, de la inmediación del juez con las partes. Por lo tanto, en la medida que existen dos modelos procesales en la misma norma, coexisten dos modelos de juez sustancialmente diferentes.

Lo cierto es que, por poderes del juez deben entenderse aquellas potestades que le son propias en virtud de un mandato estatal y que constituyen la base de su actuación no solo en la dirección e impulso del proceso, sino también en la toma de decisiones; funciones todas que conforman lo que comúnmente se conoce como actividad jurisdiccional. Los poderes del juez abarcan -entonces- dos direcciones, una estrictamente procesal asociada a impulsar los actos del proceso, de cara a lograr una impartición de justicia expedita y eficiente; y otra que respalda y justifica su intromisión en asuntos que le estaban reservados originalmente a las partes, como paliativo al principio dispositivo, que son los conocidos y polémicos "poderes instructorios", derivados -fundamentalmente- de la regulación legal de su iniciativa probatoria. El otorgamiento de mayor o menor iniciativa probatoria al tribunal se

\footnotetext{
${ }^{9}$ La visión sobre el proceso civil del alto magistrado cubano, y su propuesta de código puede encontrarse en De MonTAGú, G., Origen y formación del proceso civil moderno, Ed. Cultural S.A., La Habana, 1951.

${ }^{10}$ Se hace referencia, primero, a las instrucciones 186 y 187 de 2007, y luego a la 216 y 217 de 2012, y más reciente a la 226 de 2013, todas del CGTSP. Aunque todas constituyen referente en cuanto a los poderes del juez, particular relevancia merece la Instrucción 216, que en relación con las prerrogativas del juzgador amplió los contornos de la función jurisdiccional en sede familiar, fundamentalmente en materia de legitimación, prueba, régimen cautelar, ejecución e inmediación con las partes; y que ha tenido repercusión directa en el proceso civil con la entrada en vigor de la Instrucción 217 primero, y la 226 después.
} 
encuentra siempre en relación con la finalidad del proceso civil y, sobre todo, con el reconocimiento de la vocación garantista de la jurisdicción; sin dejar de lado, por supuesto, la función de la prueba en el debate judicial.

En este contexto, no puede perderse de vista que, tras la entrada en vigor de la nueva Constitución de la República de Cuba, el 10 de abril de 2019 ${ }^{11}$, no solo se consagran las supremas garantías de la tutela judicial efectiva ${ }^{12}$ y el debido proceso ${ }^{13}$, sino que se ordena la puesta en marcha de un amplio proceso de reforma de la legislación vigente, entre las que destacan por su lugar privilegiado en el cronograma legislativo aprobado por el parlamento cubano, las reformas a la Ley de los Tribunales de los Tribunales Populares, la Ley de Procedimiento Penal y la Ley de Procedimiento Civil, Administrativo, Laboral y Económico $^{14}$. Por tanto, el proceso civil cubano está abocado a una inminente reforma, por lo que su modelo de juez, llamado a garantizar la tutela judicial y el debido proceso establecidos, debe resultar reformado en no pocos aspectos, incluida su iniciativa probatoria. De ahí que las valoraciones que a continuación se realizan se muevan en el campo de la norma procesal vigente, con énfasis en las reformas ya acontecidas y en el perfil ideológico del legislador procesal cubano; pero también en el del anteproyecto del nuevo Código de

\footnotetext{
${ }^{11}$ Constitución de la República de Cuba, publicada en Gaceta Oficial, núm. 5, edición Extraordinaria, de 10 de abril de 2019, en vigor desde la misma fecha.

12 Art. 92: El Estado garantiza, de conformidad con la ley, que las personas puedan acceder a los órganos judiciales a fin de obtener una tutela efectiva de sus derechos e intereses legítimos. Las decisiones judiciales son de obligatorio cumplimiento y su irrespeto deriva responsabilidad para quien las incumpla.

${ }^{13}$ Art. 94: Toda persona, como garantía a su seguridad jurídica, disfruta de un debido proceso tanto en el ámbito judicial como en el administrativo y, en consecuencia, goza de los derechos siguientes:

a) disfrutar de igualdad de oportunidades en todos los procesos en que interviene como parte;

b) recibir asistencia jurídica para ejercer sus derechos en todos los procesos en que interviene;

c) aportar los medios de prueba pertinentes y solicitar la exclusión de aquellos que hayan sido obtenidos violando lo establecido;

d) acceder a un tribunal competente, independiente e imparcial, en los casos que corresponda;

e) no ser privada de sus derechos sino por resolución fundada de autoridad competente o sentencia firme de tribunal;

f) interponer los recursos o procedimientos pertinentes contra las resoluciones judiciales o administrativas que correspondan;

g) tener un proceso sin dilaciones indebidas, $y$

h) obtener reparación por los daños materiales y morales e indemnización por los perjuicios que reciba.

${ }^{14}$ En virtud de la Disposición Transitoria Décima de la Constitución, que ordena al Consejo de Gobierno del Tribunal Supremo Popular, en el plazo de 18 meses luego de su entrada en vigor, para que presente a la Asamblea Nacional del Poder Popular los anteproyectos de ley correspondientes, lo que debe acontecer en diciembre de 2020. El cronograma legislativo para el período 2020-2023, aprobado por la Asamblea Nacional del Poder Popular, en su sesión ordinaria de 21 de diciembre de 2019, mediante Acuerdo No. IX-49, puede consultarse en https://www.gacetaoficial.gob.cu/pdf/GOC-2020-O2.pdf.
} 
Procesos, siempre con la brújula apuntando hacia dónde los debates se tornan más acuciantes, como es la materia probatoria.

\section{La base ideológica de los poderes del juez en materia civil}

La creación del Derecho, indica TARUFFO, no está exenta de contaminación ideológica, ni de la influencia del poder estatal en cada circunstancia histórica, ni de las tradiciones que conforman el estrato social y la estructura económica ${ }^{15}$. Por lo tanto, el fenómeno jurídico, en toda su amplitud, nunca se manifiesta puro y constituye reflejo de una u otra ideología.

En esta dirección, el cambio de paradigma en la concepción del papel del juez y de las partes en el proceso civil ha sido -quizás- la cuestión que más polémica ha aportado la ciencia procesal desde su surgimiento en el siglo XIX. La reforma procesal austriaca de 1895 significa un giro radical en la forma de concebir el proceso civil, toda vez que el fenómeno de la publicización cuestiona el cometido de algunos sus principios raigales, particularmente del dispositivo y el de aportación de parte. La nueva distribución de las funciones de los sujetos procesales refuerza la posición jerárquica del juzgador respecto a los litigantes, a través de un incremento sustancial de sus poderes.

La promulgación del Código Procesal italiano de 1940 fija el sustrato ideológico de la polémica $^{16}$. De un lado, se sostiene la idea de códigos liberales, que modelan un tipo de juez "garantista" de los derechos e intereses legítimos de las partes, cuando el Estado promueve el estandarte de la libertad individual con intervención mínima en la vida de los particulares,

\footnotetext{
${ }^{15}$ TARUfFo, M., "Ideologías y teorías de la justicia civil", en RAmírez CARVAJal, Diana (Coord.), Proceso judicial y cultura. Una mirada global, Ed. Universidad de Medellín, Medellín, 2013, pp. 23 y ss.

${ }^{16} \mathrm{La}$ mejor explicación de este código se encuentra en su exposición de motivos, la denominada "Relación Grandi", que firma y presenta al rey de Italia el Ministro de Justicia italiano Dino GrANDI. Contiene los aspectos técnicos más relevantes de la reforma procesal italiana, a saber: la posición y evolución del problema de la reforma, que califica al nuevo código de fascista, pero reconoce que el proceso civil tiene por finalidad la resolución de conflictos privados, sin menoscabo del interés público que le asiste al Estado; el juez y su apego irrestricto a la ley, negándole cualquier posibilidad creadora de Derecho; el fortalecimiento de los poderes del juez en la dirección del proceso, al conferirle una posición prominente y reguladora, tanto en el orden procesal como en el sustantivo; la proyección jurisdiccional de los derechos subjetivos a través del principio dispositivo, como expresión del poder de disposición de las partes, pero en equilibrio con el inquisitivo, en virtud del interés público en la solución de los litigios. Asimismo, promueve el principio de adaptación del procedimiento a las exigencias de la causa, sin afectar la legalidad, pero sobre la base de la idoneidad formal según el acto procesal de que se trate; y, no menos importante, introduce modificaciones necesarias para el tránsito hacia un régimen libre de valoración de la prueba. Cfr. GRANDI, D., "La Relación Grandi", en De Cellis, F. y J. Dassen (Trads.), Código de Procedimiento Civil italiano. Exposición de motivos, Ed. Depalma, Buenos Aires, 1944.
} 
lo que encuentra expresión en el proceso judicial en la figura del juez, que debe mantenerse distante de la litis y de las partes hasta el dictado de la sentencia; de otro, aquellos códigos calificados de sociales, autoritarios e incluso totalitarios, que por regular un papel activo del juez en la dirección del proceso, pareciere que mutilan la iniciativa de las partes en la defensa de sus posiciones procesales respecto a un litigio concreto.

Punto de partida -esencial- para comprender mejor el tema puede encontrarse en la obra de Alcalá-Zamora. Con autoridad explica que, "Puesto que liberalismo y autoritarismo son etiquetas tomadas del campo político, procede dilucidar, ante todo, si la forma y métodos de gobierno imperantes en un país en un momento dado, repercuten ineludiblemente sobre el enjuiciamiento respectivo, o si, por el contrario, integran actividades que se mueven en órbitas distintas"17; para concluir luego que "si mediase siempre correlación indisoluble entre situación política y enjuiciamiento, (...) el mecanismo procesal sería un continuo tejer y destejer, cuando, como regla, (...) exhibe una estabilidad incomparablemente mayor que la de los regímenes políticos respectivos" ${ }^{\text {"18 }}$. Esta ha sido, en juicio propio, la gran ventaja de los sistemas procesales respecto a los regímenes políticos, a la vez que ha sido la camisa de fuerza, bajo el sello de reticencia legislativa, para frenar no pocas veces- las reformas procesales.

No puede buscarse en la esfera política lo que ha de encontrarse en la ordenación jurídica del proceso, fundamentalmente en sus principios políticos y en los aspectos técnicos que guían el procedimiento. No debe llevarse al plano procesal el concepto de democracia, pues una cosa es el acceso sin obstáculos a la justicia, la existencia de tribunales predeterminados a los hechos del proceso, el sistema popular de elección de los jueces o la organización escabinada de los órganos jurisdiccionales, y otra distinta la posición de las partes en la contienda judicial -en relación con el juzgador-, que identifica doctrinalmente al proceso como liberal o autoritario. Tampoco puede identificarse el carácter ideológico del proceso con el eventual quebrantamiento del principio de independencia, cuando la función

\footnotetext{
${ }^{17}$ En su clásico "Liberalismo y autoritarismo en el proceso", el maestro español pone de manifiesto la necesidad de establecer los elementos que hacen posible la coexistencia de ambos modelos en un andamiaje procesal único, puesto que en materia de proceso civil no existe un modelo puro. Cfr. ALCALÁ-ZAMORA Y CASTILLO, N., Estudios de Teoría General e Historia del Proceso (1945-1972), Tomo II: Números 12-30, Ed. Universidad Nacional Autónoma de México, México D.F., 1992, p. 253.

${ }^{18}$ Ídem, pp. 258-259.
} 
jurisdiccional se supedita a la ejecutiva; o cuando se rompe la imparcialidad del tribunal por la influencia de factores subjetivos que coartan su actividad.

Explica BERIZONCE que la perspectiva ideológica que se tenga del proceso incide en no pocos de sus elementos configuradores, pero de manera particular sobre su finalidad $u$ objeto, la distribución de los papeles asignados al juez y las partes, la estructura del procedimiento y la regulación de las pruebas ${ }^{19}$. El profesor argentino parte de la finalidad del proceso, porque en función de ello corresponde un determinado sistema de relaciones entre las partes y el tribunal, con matices hacia lo público o lo privado, en dependencia de la posición que se tenga respecto a las prerrogativas de las partes y los poderes del juez. Reconoce, igualmente, la importancia de un procedimiento bien estructurado y de la oralidad como principio que le guía, pues asegura el contacto constante del juez con los justiciables y la aplicación directa y expedita de sus poderes de dirección e instrucción cuando la situación procesal lo demanda y, como consecuencia de ello, coloca al juez en mejor posición para la valoración de la prueba, en función de su propia racionalidad y prudencia. El juez se convierte, entonces, en el principal responsable de la observancia de las garantías procesales consagradas en los textos constitucionales.

TARUFFO, en posición sincrética, es del criterio que un modelo procesal es expresión de la combinación de opciones ideológicas y de los aspectos técnicos que conforman el procedimiento $^{20}$, pensamiento que deja establecido que el proceso no es puramente una cuestión de tipo ideológica, ni totalmente técnica; aunque lo complicado en cualquier valoración que se haga es siempre la dimensión ideológica, pues la técnica se mantiene normalmente- estática.

En suma, resulta harto difícil encontrar un código que responda únicamente a uno de los modelos antes señalados, más bien puede comprobarse la tendencia hacia uno u otro, en dependencia de la regulación de los elementos esenciales del proceso. No ha existido, ni existe, consenso en la doctrina al respecto, pues como bien destaca Picó I JUNOY, unas y otras tesis respecto a la ideología del proceso, son más o menos admisibles ${ }^{21}$. Negar el

\footnotetext{
${ }^{19}$ Vid. BerizonCE, R., "Ideologías y proceso", en Mendoza DíaZ, J., "El Derecho Procesal y los retos de la contemporaneidad", Ed. Universidad Católica de Santiago de Gauayaquil, Santiago de Guayaquil, 2017, p. 55. ${ }^{20}$ Vid. TARuffo, M., Páginas sobre justicia civil, traducción de Maximiliano Aramburo Calle, Ed. Marcial Pons, Madrid, 2009, pp. 195-196.

${ }^{21}$ PICÓ I JunOY, J., "Ideología y proceso... In medio virtus", en Justicia. Revista de Derecho Procesal, núm. 2, 2016, p. 81.
} 
carácter ideológico del proceso civil, con fundamento en el carácter técnico que le caracteriza, constituye un error. Sin embargo, el perfil ideológico del proceso no tiene necesariamente que coincidir con los principios económicos, políticos y sociales establecidos constitucionalmente por el Estado. No son pocos los ejemplos que lo demuestran, como el caso de Italia y Alemania en la primera mitad del siglo pasado, que bajo un régimen estatal fascista promulgan leyes procesales de corte publicista; o de la propia Cuba, que siendo un país socialista que ampara legalmente la iniciativa del juez, se ha mantenido fiel al solemnis ordo iudiciarium español del siglo XIX, de tipo liberal. Lo anterior quiere decir que una cosa es la ideología política del Estado y otra la ideología del proceso, que bien pueden coincidir en su esencia ${ }^{22}$, pero también pueden ser diferentes, opuestas y convivir armónicamente.

\subsection{Garantismo procesal y activismo judicial a debate}

El proceso civil ha dejado de ser, desde hace algún tiempo, un mero mecanismo de resolución de conflictos privados. Su carácter público le imprime el sello de la búsqueda del bienestar colectivo, a partir de la aplicación del Derecho objetivo al caso concreto. Como advierte GONZÁLEZ ÁLVAREZ, la publicización del proceso permite que junto a su función inmediata -solución de un conflicto intersubjetivo- se coloque en igual medida la mediata, que es la actuación del ordenamiento jurídico como expresión del actuar público, para alcanzar la justicia ${ }^{23}$. De esta forma, las partes disponen del objeto del litigio, mas no del desarrollo del proceso, función que corresponde al tribunal.

Sin embargo, el posicionamiento del juez como director del proceso encuentra férreos detractores, al punto de concebirse como bloque dogmático compacto y opuesto a cualquier actividad que ponga en peligro la libertad y los derechos de las partes. Movimiento doctrinal

\footnotetext{
${ }^{22}$ Los más coherentes en este sentido han sido, en su época, los ordenamientos procesales de corte decimonónico y los ordenamientos socialistas soviéticos, que enarbolan las banderas del liberalismo y el intervencionismo estatal con aplicación práctica al proceso, a través de la figura de un juez inerte los primeros y de un juez activo los segundos. Sin embargo, aunque la doctrina soviética se pronuncia sobre el nacimiento de una nueva familia jurídica, la socialista, que incluso elimina de su acervo literario cualquier referencia occidental, las instituciones que integran el Derecho soviético pertenecen al sistema romano-francés, a pesar de que el sistema económico, político y social sea diferente al de la mayoría de los países que integran el sistema continental, lo que demuestra que en materia jurídica nada es absoluto.

${ }^{23}$ Vid. GONZÁLEZ ÁLVAREZ, R., "Eficientismo y garantismo procesales en serio: pasando la página del debate entre publicismo y dispositivismo procesales”, en Derecho y Sociedad, núm. 38, 2012, p. 290.
} 
de corte dispositivista, autodenominado garantista, que atribuye el calificativo de autoritaria a cualquier conducta procesal de oficio que se inmiscuya en la esfera material del litigio. Para esta corriente de pensamiento, el logro de la paz y la justicia sociales discurre de la mano de un juez que respete las garantías del proceso; obediencia que se traduce en una actividad pasiva -entiéndase nula- del juzgador frente a la litis. De esta manera, se concibe el proceso como mecanismo de solución de controversias, no como cauce para la realización de la justicia.

El dispositivismo procesal no solo implica la sumisión del tribunal al objeto del proceso y los puntos en litigio que conforman el debate judicial; sino que lo sujeta a la aportación de los hechos por las partes. Por tal razón, el tribunal no debe disponer la práctica de uno o más medios de prueba que considere imprescindibles para arribar a una decisión justa, pues debe fallar acorde al resultado obtenido de la regla del onus probandi. No se toma en cuenta el concepto de carga procesal, en el entendido que constituye autorresponsabilidad de las partes llevar a cabo la actividad probatoria. Actuación que puede ser desplegada eficientemente, o bien no puede serlo por no contar con los medios idóneos -aunque sea la intención-; o simplemente no ser llevada a cabo diligentemente porque no conviene, ya que la prueba aportada por una de las partes, una vez unida al proceso, sirve a ambos litigantes.

Eliminar la iniciativa probatoria del tribunal constituye objetivo claro del garantismo procesal, ya que la prueba constituye actividad exclusiva de las partes; criterio que tiene basamento en la imparcialidad del tribunal, o mejor, en su impartialidad, que se quebranta si el juez se sale de los esquemas establecidos. La imparcialidad no constituye, de esta forma, garantía para la justicia, sino para la libertad de movimiento de las partes mientras dure el pleito. No puede negarse que los derechos de las partes están conectados con la actuación imparcial del tribunal, pero ello no puede significar que la imparcialidad se erija en manto protector de la irresponsabilidad, negligencia y mala fe procesales. No es responsabilidad del tribunal, en consecuencia, la garantía de la lealtad y probidad en el debate judicial.

Se defiende así un concepto de debido proceso que se perfila absoluto, intocable e inalterable. Lo debido, en este caso, no es tutela del tribunal como derecho abstracto, sino el respeto a la libertad individual; de ahí que el contradictorio, y la igualdad procesal que ello supone, dependen de que esa "libertad" no se vea afectada por el actuar oficioso de la judicatura. Las garantías del proceso, entonces, se encuentran en función de la libertad 
personal. El juez desempeña -según este modelo- un papel residual, de mero moderador o facilitador del debate, por lo que debe dejar transitar la litis como mejor convenga a las partes.

Por supuesto, la autodenominación de "garantista" excluye cualquier posibilidad de que un modelo opuesto lo sea y, cualquier variante de actuación activa del juez, lo convierte en autoritario. Incluso, las más recientes tesis revisionistas, de la mano de destacados procesalistas como Montero Aroca, Monteleone, Cirpriani y Alvarado Velloso, en pleno siglo XXI aún niegan los aportes del carácter publicista del proceso $^{24}$; crítica que centra su atención en la negativa de iniciativa probatoria del tribunal, producto de la posible ruptura de la imparcialidad judicial que ello puede generar; así como en el control de oficio de la buena fe procesal en la conducta de las partes, que coarta la autonomía privada. Negarle toda iniciativa material al juez, implica restarle efectividad y eficacia al proceso, en su carácter de instrumento idóneo para alcanzar la tutela judicial efectiva de los derechos e intereses legítimos en juego. En este sentido, plantea con acierto PICó I JUNOY que "lo relevante no es si el juez debe tener iniciativa probatoria o no, o si debe velar por el respeto a la buena fe de las partes, sino cuáles deben ser los límites de tales iniciativas"25.

Del otro lado de la cuerda del debate, el activismo judicial, como se conoce, defiende la idea de un juez con un papel protagónico en el proceso. No se trata de ser protagonista del conflicto, porque ello es responsabilidad de los justiciables, sino de coadyuvar con su actuación al logro de la justicia, a través de un fallo acorde a la verdad y a Derecho objetivo; modelo que propicia la intervención del juez a través de un conjunto de poderes-deberes que constituyen el contenido de la actividad jurisdiccional.

Con la consagración constitucional de las garantías procesales se consolida el carácter público de la función jurisdiccional, en tanto se abre paso a la idea de proceso útil y justo, a

\footnotetext{
${ }^{24}$ Vid. respectivamente MONTERO AROCA, J., Los principios políticos de la nueva Ley de Enjuiciamiento Civil. Los poderes del juez y la oralidad, Ed. Tirant lo Blanch, Valencia, 2001, pp. 60-61; MonTELEONE, G., "Principios e ideologías del proceso civil: impresiones de un revisionista", en MONTERO AROCA, J. (Coord.), Proceso Civil e Ideología ..., ob. cit., pp. 105-116; CIPRIANI, F., "El proceso civil italiano entre eficiencia y garantías, en CIPRIANI, F., Batallas por la justicia civil - Ensayos, traducción de Eugenia Ariano Dehu, Ed. Cultural Cuzco, Lima, 2003, pp. 166 y ss; Alvarado Velloso, A., Garantismo procesal contra actuación judicial de oficio, Ed. Tirant lo Blanch, Valencia, 2005, pp. 61-166.

${ }^{25}$ PICó I JunOY, J., "El Derecho Procesal entre el garantismo y la eficacia: un debate mal planteado", en Derecho y Sociedad, núm. 38, 2012, p. 280.
} 
partir del redimensionamiento de sus principales caracteres ${ }^{26}$. El proceso tiene que serle útil a los justiciables, en el entendido de que puedan satisfacer sus intereses y derechos, pues otra cosa quedaría en el plano de lo puramente formal. El proceso ha de ser, igualmente, justo ${ }^{27}$; idea que parte del concepto mismo de tutela judicial efectiva y, sobre todo, de los elementos que la componen, o sea, cuando se tiene pleno acceso a la justicia, cuando se observan todas las garantías procesales y cuando existen eficaces mecanismos de ejecución.

Esta idea de proceso descansa también en su aparato formal, o sea, en la necesidad de contar con procedimientos diferenciados para obtener una tutela, también diferenciada, de los derechos de los justiciables, sobre todo en aquellos casos que tienden a la salvaguarda de intereses superiores. Por supuesto, corresponde al juez la garantía del contradictorio en un marco de igualdad procesal, pues si importante resulta un procedimiento bien estructurado, de mayor relevancia es que en el tránsito de una fase a otra de ese cauce procesal las partes cuenten con iguales posibilidades de defensa. Por lo tanto, atributo esencial de la tutela judicial efectiva es, también, el derecho al procedimiento adecuado ${ }^{28}$.

En esta misma tesitura, el sistema probatorio debe estar signado por la búsqueda de la verdad para alcanzar la justicia. Finalidad que no solo constituye la función teleológica de la prueba, sino que depende - en buena medida- de la regulación que sobre la admisión y denegación, práctica y valoración de los medios de prueba exista. Si bien la cuestión se centra, tradicionalmente, en la valoración de la prueba, con la reconocida tendencia a la libre apreciación por el tribunal, no puede perderse de vista que la actividad probatoria constituye la columna vertebral del proceso y cada una de sus etapas resulta crucial para alcanzar certeza sobre los hechos.

\footnotetext{
${ }^{26}$ Los nuevos paradigmas del proceso civil exigen un replanteamiento de las principales categorías e instituciones de la ciencia procesal. La presencia de nuevos actores ha ensanchado los contornos de la legitimación, así como también se aprecia un mayor protagonismo de los jueces, no pocas veces acompañantes de las partes y de sus derechos e intereses legítimos -sobre todo en los procesos familiares o de corte no dispositivo-, la tendencia a la oralidad y la inmediación del juez con las partes y con los hechos, la presencia de tutelas judiciales urgentes que anticipan el resultado procesal, la flexibilización de las formas y del principio de preclusión, conducen a pensar en que el proceso civil moderno constituye el reservorio natural para alcanzar la tutela judicial efectiva.

${ }^{27}$ Sobre la idea de proceso justo, en el sentido que se expone, vid. MASCIOTRA, M., "Lineamientos del proceso civil", en El Derecho. Diario de Doctrina y Jurisprudencia, Ed. Universidad Católica Argentina, núm. 14057, Año LIV, 2016, p. 3.

${ }^{28}$ BERIZONCE pone de manifiesto que la "universalización que supone el proceso ordinario se torna anacrónica y ha de ceder frente a los tipos diferenciados sumarios", ello en virtud de que "No cabe admitir que el proceso civil vaya a desligarse del papel que el derecho material y los derechos fundamentales desempeñan en la sociedad". BERIZONCE, R., "Ideologías..., ob. cit., p. 62.
} 
De esta forma, la admisibilidad o no de un medio de prueba -sobre todo esta últimadebe fundarse en los criterios objetivos correspondientes, así como la posibilidad de impugnación de la resolución judicial correspondiente. Lo mismo sucede con su práctica, sobre todo cuando la parte a quien legalmente corresponde la carga probatoria no se encuentra en condiciones para ello; de ahí que el juez pueda, en virtud de sus poderes directivos, desplazar la responsabilidad de probar a la parte que se encuentre en mejor situación para hacerlo. Poder facultativo del juez que se realiza a través de las denominadas cargas probatorias dinámicas, interactivas o fluyentes, de tipo excepcional pero que tributan directamente a la materialización de la tutela judicial efectiva.

Por supuesto, el sistema probatorio se completa con la potestad del juzgador para ordenar la práctica de uno o más medios de prueba que considere imprescindibles para la resolución del litigio; elemento que ha sido la punta de lanza de la doctrina dispositivista para hacer notar que tal prerrogativa afecta la eficacia del proceso, o sea, su resultado. Sin embargo, la eficacia o ineficacia procesal no radica en la posibilidad de que el juez tenga o no iniciativa probatoria, sino en la utilización de esta herramienta para la búsqueda de la verdad y la creación de convicción que permita arribar a un fallo justo. Objetivo que se logra cuando los jueces cuentan con poderes suficientes para llevar a vías de efecto una actividad jurisdiccional que respete los principios y reglas que dicta la Constitución y las leyes procesales; ello en el marco de una verdadera justicia de acompañamiento ${ }^{29}$.

Tampoco puede imputarse a la imparcialidad, o a su eventual quebrantamiento, la "necesidad" de eliminar de golpe la iniciativa probatoria del tribunal. La ordenación oficiosa de la práctica de un medio de prueba no se lleva a cabo para beneficiar a una sola de las partes -que puede resultar vencedora o no-, sino en beneficio de las dos para arribar a un fallo justo según las circunstancias del caso. El propio principio dispositivo, el contradictorio procesal y la igualdad de armas, constituyen límites naturales a la actuación del juez y a su parcialidad. La imparcialidad, además de ser una cualidad inherente a la condición de juez, es una garantía de las partes en el proceso; de ahí que cualquier lesión en este sentido debe ser reparada.

La eficacia del resultado procesal no está dada únicamente por el respeto impoluto a lo dispositivo, sino por la observancia que de este principio realice el tribunal en relación 
con lo que resulte más justo para los justiciables. El manto constitucional protector que conforman el debido proceso y la tutela judicial efectiva -con mayor amplitud- refuerzan el sello tuitivo de la función jurisdiccional y, como resulta consustancial a la jurisdicción la protección de los particulares, el juez no puede permanecer ajeno a la litis. Los poderes materiales del juez asumen, por tanto, una función de garantía, no solo porque se destinan a salvaguardar la buena fe y la verdad en el proceso, sino porque encuentran límite en los principios políticos de este, en el propio estatuto que otorga la condición de juez y en el sistema de responsabilidad que le es inherente.

Queda claro entonces que la inactividad o protagonismo de los jueces en el proceso está en estrecha relación con los principios relativos a las formas de enjuiciamiento, que entroncan directamente con los principios relativos al objeto del proceso. Lo cierto es que dispositivo e inquisitivo deben convivir -como de hecho lo hacen- en los contornos del proceso civil, pues no existe proceso puramente dispositivo, como tampoco puramente inquisitivo. El equilibrio entre ambos convierte al proceso civil el escenario propicio para alcanzar la justicia, porque la iniciativa privada no es absoluta, como tampoco lo son los poderes del juez. La existencia de jueces activos en el proceso no es sinónimo de autoritarismo o de la existencia de una dictadura procesal, sino de lo que pudiera denominarse el verdadero garantismo procesal.

\section{Reformas procesales en Cuba, poderes del juez y el perfil ideológico del} legislador

En la década de los setenta del pasado siglo tiene lugar la gran reforma procesal en el campo de los procesos civil y penal en Cuba. En el orden civil, con la promulgación de la Ley No. 1261, Ley de Procedimiento Civil y Administrativo, se pone fin a la vigencia del enjuiciamiento español, pero no al modelo procesal que lo inspira. En 1977 se aprueba la Ley No. 7, de 19 de agosto, que incorpora al texto el proceso laboral, por lo que la ley asume su identificación como Ley de Procedimiento Civil, Administrativo y Laboral; norma vigente en la actualidad, a pesar de las diversas modificaciones que se le han introducido. Las transformaciones esenciales introducidas en 1977 se encaminan al fortalecimiento del papel del juez en la conducción del proceso, así como de específicas potestades para 
intervenir en el fondo del litigio, pero el modelo procesal continúa siendo el solemnis ordo iudiciario, heredado de España, por lo que el proceso judicial permanece esencialmente escrito, preclusivo y lento.

No es hasta 2006, con la promulgación del Decreto Ley No. 241, de 26 de septiembre, que se percibe un cambio en la concepción de los procesos de corte no penal; reforma que modifica algunos aspectos del proceso civil, a la vez que introduce una cuarta parte en la ley rituaria, dedicada al proceso económico ${ }^{30}$ y que modifica su denominación a Ley de Procedimiento Civil, Administrativo, Laboral y Económico (LPCALE). En su aspecto técnico, el proceso económico se diseña para garantizar un juzgamiento por audiencias, dedicadas a sanear, practicar pruebas y escuchar los alegatos de las partes respectivamente, con énfasis en la inmediación y celeridad procesal, haciendo más efectivos los principios de igualdad y contradicción, así como alcanzar, en lo posible, la certeza sobre los hechos alegados por las partes ${ }^{31}$.

Con las reformas procesales en materias no penales en Cuba, fundamentalmente la ocurrida en 2006, se renuevan algunas instituciones, pero sin alterar significativamente el sistema a reformar en lo civil, de ahí que la doctrina cubana, al comentar el paralelismo existente entre este y el económico, haga referencia al necesario "reacomodo" de los

\footnotetext{
${ }^{30}$ Modalidad procesal dedicada a la resolución de conflictos que se susciten entre personas naturales o jurídicas, nacionales o extranjeras con representaciones o bienes o intereses en Cuba, con motivo de sus relaciones contractuales, salvo cuando se contraigan a la esfera del consumo de la población cubana. Parece ser que la motivación del legislador en crear este nuevo tipo procesal lo constituye el interés por brindar una tutela diferenciada a determinados conflictos vinculados con las relaciones que se producen en el campo de la contratación mercantil y la inversión de capital extranjero, fundamentalmente (Cfr. art. 739 de la LPCALE, respecto a la jurisdicción y competencia de lo económico). Como se aprecia, se trata de las controversias que surgen de la ejecución de los contratos comerciales; no obstante, la jurisdicción que resuelve este tipo de casos se le apellida económica, a tono con la tradición socialista respecto a las relaciones económicas, consagrada en el texto constitucional de 1976 y que se renueva en la nueva Constitución de la República de 2019 (Cfr. art.s del 18 al 32 de la Constitución de la República de 2019, que corresponden a los fundamentos económicos del Estado cubano).

${ }^{31}$ La reforma contenida en el Decreto Ley 241/2006 pondera la proactividad de la judicatura en la tramitación del proceso, tanto así, que el tribunal cuenta con prerrogativas relativas al saneamiento del proceso, realizar acciones preparatorias una vez iniciado el trámite procesal, la celebración de comparecencia, facultades propias dela actividad probatoria y otras relativas al poder cautelar. Este modelo procesal introduce un nuevo espíritu en la judicatura cubana, que aprecia cómo en esta materia los asuntos encuentran una solución más efectiva y rápida que en el resto de las materias no penales, lo que propicia que el Tribunal Supremo Popular, a partir de importantes decisiones de su Consejo de Gobierno (CGTSP), decida cambiar la cara del enjuiciamiento en el campo del Derecho Civil y de Familia en Cuba. Tal es así, que sus Instrucciones núms. 216, 217 y más recientemente la 226, con la finalidad de promover una práctica judicial uniforme en materia familiar y civil, expresan con claridad la intención de introducir mecanismos que posibiliten ampliar la interacción de los tribunales con las partes, así como la necesidad de un proceso más breve y predominantemente oral, todo lo cual encuentra fundamento en las más modernas tendencias del Derecho Procesal. Con razón se ha dicho que las modificaciones en sede familiar y civil constituyen una labor judicial, más que legislativa.
} 
principios troncales del primero, puesto que sigue siendo esencialmente rígido, escriturado y con escasos momentos de contacto del juez con las partes $^{32}$. Con esta última reforma, el legislador cubano dota al nuevo diseño procesal de los principios de oralidad, inmediación, concentración y publicidad, mientras que para el resto de los tipos procesales solo operan a manera de supletoriedad inversa ${ }^{33}$.

Pero no puede perderse de vista que la reforma procesal de los años setenta coloca al proceso civil cubano a la vanguardia de los ordenamientos que promueven la idea de un juez activo en su tramitación. La existencia de un capítulo específico dedicado a las facultades del tribunal, y otras atribuciones dispersas a lo largo de su articulado así lo demuestra. Tales "facultades" se concentran en la regulación de los artíuclos del 38 al 45 de la LPCALE y constituyen los principales poderes de actuación del órgano juzgador en el proceso civil.

De manera general, basta decir que el tribunal puede -de oficio- disponer las medidas necesarias para garantizar la igualdad de las partes en el proceso, evitar dilaciones innecesarias y concentrar las diligencias que pudieran practicarse conjuntamente, velar por la lealtad y probidad en el juicio, hacer comparecer a las partes en cualquier estado del proceso para interrogarlas sobre los hechos del proceso $^{34}$, resolver determinadas cuestiones que - $a b$ initio- no fueron incluidas en el objeto del debate, previa alegaciones y aportación de pruebas por las partes, además de ordenar la práctica de diligencias probatorias necesarias para el cabal conocimiento de los hechos.

\footnotetext{
32 En el ámbito familiar, al no existir en Cuba un proceso especial para la solución de estos casos, las controversias se han tramitado históricamente a través de los cauces y reglas del proceso civil tradicional, por lo que cuestiones tales como la indisponibilidad del objeto del proceso, la intervención preceptiva del fiscal, las amplias facultades probatorias del juez, las posibilidades cautelares, la legitimación, entre muchas otras que caracterizan el Derecho Procesal de Familia, no están presentes en la normativa procesal cubana. Sin embargo, en 2012 el CGTSP dicta la Instrucción núm. 216, que regula el procedimiento para este tipo de conflictos y dota al juez de útiles herramientas que le convierten en acompañante de las partes y garante no solo del debido proceso, sino de los intereses superiores que se ventilan en este tipo de procesos.

${ }^{33}$ Recuérdese que el proceso modelo sigue siendo el ordinario civil, por lo que solo se puede mirar al económico, de manera supletoria, cuando no exista regulación específica en aquel, como es el caso del catálogo de medidas cautelares cuya aplicación se extiende al proceso civil, que solo regula el embargo preventivo. Supletoriedad que, como ha acuñado en más de una ocasión el profesor MENDOZA DíAZ, se lleva a cabo de manera inversa, pues lo atinado -técnicamente hablando- es mirar siempre al proceso civil -ordinario- como proceso modelo.

${ }^{34}$ La existencia - por ejemplo- de una eventual audiencia de naturaleza facultativa, al amparo del art. 42 de la LPCALE, se convierte en actividad de carácter preceptivo, con la entrada en vigor de las Instrucciones 216 y 217 del CGTSP, de 2012, para los procesos familiar y civil respectivamente, de tal suerte que le sirve al tribunal para sanear el proceso, delimitar los términos del debate, propiciar la conciliación y ventilar las cuestiones probatorias que puedan quedar zanjadas en el momento de su realización, una vez vencida la fase de alegaciones.
} 
A pesar de los aspectos significativos que en materia de potestades del tribunal contiene la LPCALE, es lo cierto que su aplicación en la práctica judicial ha sido muy escasa, prácticamente nula. En esta tesitura, puede sostenerse que la LPCALE carece de una posición ideológica concreta, fundamentalmente en lo relativo a las posibilidades de actuación del juzgador y su relación con las partes. Dicho de otro modo, parece que el cometido del proceso civil cubano y de su modelo de juez queda claramente establecido en su faz estática o legal, en cuanto a otorgarle poderes procesales y materiales, pero ello no ha encontrado expresión material en su faceta dinámica.

El proceso civil patrio ha seguido los patrones de actuación de la derogada Ley de Enjuiciamiento Civil española (LEC) y, aunque se le introducen algunas de las propuestas contenidas en el Proyecto Montagú de 1951 y se regula un capítulo dedicado a las facultades del tribunal, con influencia de los aires publicistas del Derecho Procesal Civil soviético ${ }^{35}$, tales prerrogativas no calan en la mente de los jueces, que las asumen con carácter facultativo, a partir de la propia nomenclatura que le atribuye la ley. Como resultado, el juez cubano - aun dotado de poderes suficientes- no adopta una posición activa en la conducción del proceso, como tampoco suele interferir en el aspecto material de la litis, a través de sus poderes instructorios.

La afirmación anterior no parece tener sentido en el escenario político-ideológico nacional, puesto que ha sido preocupación del Estado socialista cubano no solo la estructura

\footnotetext{
${ }^{35}$ Los códigos soviéticos, que desde una postura ideológica socialista, regulan un modelo de juez activo en el proceso civil, como es el caso del Código de Procedimiento Civil de 1923 y las reformas de 1964 y 1979. Sobre el papel de la judicatura soviética, destaca GURVICH que los tribunales "deben dilucidar en todos los litigios las verdaderas circunstancias del caso, así como los derechos y las obligaciones de las partes. Dicho en otros términos, los tribunales deben empeñarse por todos los medios en establecer la verdad objetiva en todos los litigios (...). Sólo de este modo puede asegurarse la auténtica defensa de los derechos subjetivos" ${ }^{" 35}$. Por ello, la tutela rápida y eficiente de los derechos y libertades de las personas requiere una actuación puntual de los tribunales. Vid. Gurvich, M. A., "Objeto y sistema de la ciencia del Derecho Procesal Civil Soviético", en Gurvich, M. A. (Dir.), Derecho Procesal Civil Soviético, traducción de Miguel Lubán, Ed. Instituto de Investigaciones Jurídicas de la Universidad Nacional Autónoma de México, México D.F., 1971, p 10.

Por su parte, MENDOZA DíaZ destaca los aspectos más relevantes del proceso civil soviético, con énfasis en los que no inciden en la reforma procesal cubana de los años setenta, a saber: la legitimación a favor de organizaciones sociales, la existencia de un proceso de conocimiento con predominio de la oralidad, la concentración y la inmediación, un abanico amplio de poderes del juez, labor conciliadora del tribunal, revisión de sentencias firmes mediante inspección judicial, así como la existencia de ejecutores judiciales y los denominados tribunales de camaradas. Sin embargo, reconoce que otras pecualiaridades del procesalismo soviético encuentran expresión normativa y científica en Cuba, como es la definición de las fuentes formales del Derecho Procesal Civil y la concepción de que constituye finalidad del proceso civil la búsqueda de la verdad objetiva, que no es responsabilidad exclusiva de las partes. Vid. MENDOZa Díaz, J., "Un acercamiento al Proceso Civil cubano", en Mendoza Díaz, J. (Coord.), Panorama del Derecho Procesal Hispanocubano, Ed. Tirant lo Blanch, Valencia, 2012, pp. 97-105.
} 
y organización del sistema judicial, sino la forma en qué se imparte justicia, de ahí que las reformas procesales del pasado siglo fijen aspectos relevantes en la concepción y finalidad del proceso civil, como es la presencia de un juez que tiene el deber de dirigir el debate judicial a buen puerto. Sin embargo, estos pilares se colocan -casi caprichosamente- en una moldura arcaica, desfasada e ideológicamente opuesta a la visión publicista del proceso.

Con las reformas procesales de los años setenta, se refuerza el impulso procesal de oficio, aspecto que se materializa en la práctica sin contratiempos, incluso en las legislaciones de corte liberal; pero no sucede igual con el resto de las facultades del tribunal, fundamentalmente las relativas al restablecimiento de la igualdad procesal, la comparecencia de las partes en cualquier estado del proceso y las que exceden el principio dispositivo material, que son las que, en definitiva, traslucen un contenido ideológico. Se evidencia, por tanto, una ruptura entre la letra de la ley y su implementación a través de la actividad jurisdiccional, por lo que aquella, si bien no perece del todo, permanece en una especie de letargo -cual vacatio legis de casi cuarenta años- hasta que el CGTSP rescata el contenido de las potestades del juzgador ${ }^{36} \mathrm{y}$, asignándole carácter preceptivo a algunas de ellas, coloca al juez en posición activa, no para disponer sobre el fondo del asunto, sino para convertirle en verdadero garante del debido proceso y la seguridad jurídica a través de una tutela judicial efectiva $^{37}$.

\section{La iniciativa probatoria en el proceso civil cubano}

Como se ha dicho, el actual proceso civil cubano responde, casi en su totalidad, a la estructura y funcionamiento del vetusto procedimiento español del siglo XIX. Es así que el juicio ordinario -modelo y supletorio para el resto de los tipos procesales, en atención a las

\footnotetext{
${ }^{36}$ La Ley de los Tribunales Populares, en su art. 19.1 inciso h), faculta al CGTSP para impartir instrucciones generales de carácter obligatorio para todo el sistema judicial, con el objetivo de garantizar una práctica uniforme en el país en el ejercicio de la función jurisdiccional. El activismo del CGTSP en los últimos años ha cambiado la práctica jurisdiccional cubana, introduciendo modelos de actuación que no tienen un desarrollo específico en la ley, pero que a partir de una interpretación extensiva de determinados arts., propicia la transformación del contexto existente en el ámbito del enjuiciamiento civil y familiar en Cuba.

${ }^{37} \mathrm{Si}$ bien los conceptos debido proceso y tutela judicial efectiva aparecen en el escenario normativo nacional a partir de la entrada en vigor de la nueva Constitución de la República, y poco después se proyecta hacia el ámbito procesal a través de la Instrucción 245 del CGTSP, no es menos cierto que la esencia de estos postulados se colige de la letra de anteriores disposiciones del mismo órgano gubernativo del alto foro, como las instrucciones núms. 216 y 217 de 2012, o de la reforma procesal de 2006, que le confieren al juez un papel protagónico en la dirección de los asuntos que se someten a su conocimiento.
} 
amplias posibilidades de alegación y prueba que ostentan los justiciables- se compone de las tres fases clásicas del proceso escriturado, o sea, alegaciones, prueba y conclusiva.

En relación con la segunda, no puede perderse de vista que el proceso civil cubano histórico, al amparo de la Ley de Enjuiciamiento Civil española de 1881, vigente hasta la década de los años setenta del pasado siglo, coloca a las partes en el epicentro de la actividad probatoria, en tanto les otorga su iniciativa tanto para el recibimiento del proceso a prueba, como para los actos de proposición y práctica. Sobre la base de este modelo, la necesidad de probar recae únicamente sobre las partes.

Sin embargo, el legislador cubano rompe con el tradicionalismo decimonónico y coloca al juzgador en posición de decidir si resulta necesario o no la apertura del proceso a prueba; una vez finalizada la fase de alegaciones, o en el mismo acto de la comparecencia que le da cierre, una vez escuchadas las posturas de las partes, fijado el objeto del debate e incluso, determinados los hechos objeto de prueba. Ello se infiere de la letra del art. 243 de la LPCALE, que regula la obligación del tribunal de dictar sentencia, sin más trámites, cuando el debate se contraiga a cuestiones de estricto derecho cuya justificación resulte de los escritos polémicos y documentos presentados; pero también la de abrir el proceso a prueba cuando los hechos introducidos por las partes requieren de posterior demostración.

En tal sentido expresa MANTECÓN RAMOS que "Es cierto que son las partes las que tienen el interés en probar, y si es así, pudiera parecer consecuente que se les permita decidir si el proceso requiere o no de fase probatoria. Sin embargo, es el tribunal el que está en el centro visual de la controversia judicial y es indudable que esta posición lo sitúa en mejores posibilidades para decidir algo tan importante como la necesidad o no de una etapa procesal, la de la prueba, que el legislador no ha querido dejar en manos de los contendientes" 38 . Se constata, de esta forma, el fenómeno de la publicización del proceso.

La lógica del proceso civil advierte que la actividad de probar corresponde a las partes, quienes no prueban para sí, ya que el destinatario de su diligenciamiento es el tribunal. Por tanto, los justiciables asumen una posición activa en esta sede, correspondiéndole al juzgador la expectativa de los hechos y los medios de prueba introducidos al proceso, ya que luego de la práctica de pruebas le corresponde su valoración y la emisión de la resolución judicial que

\footnotetext{
${ }^{38}$ MANTECón RAmos, A., "Teoría general de la prueba en el proceso civil”, en PÉREZ GutiÉRREZ, I. (Coord.), Derecho Procesal Civil, Ed. Félix Varela, La Habana, 2016, p. 158.
} 
le pone fin al litigio. En tal sentido, los códigos procesales regulan la carga de las partes de probar los hechos objeto de prueba.

Es así que el art. 244 de LPCALE regula la regla del onus probandi, por lo que a cada parte le corresponde probar los hechos que afirme y los que oponga a los presentados de contrario, así como la vigencia del Derecho extranjero cuya aplicación reclame. Se trata del precepto legal que, colocado en la antesala de la fase probatoria, resulta indicativa de la actividad a desplegar por las partes, cuando en puridad constituye una regla valorativa, de juicio, que despliega su eficacia en la fase de cierre del proceso, al momento en que el tribunal evalúa el material probatorio que obra en el expediente del caso y, sobre todo, en la sentencia. El principal problema de la carga de la prueba surge cuando la actividad probatoria desplegada por las partes no ha sido suficiente para que el tribunal arribe a convicción sobre los hechos, lo cual solo tiene sentido cuando este último aprecia tal insuficiencia.

El otro problema que presenta la regulación cubana de la carga de la prueba es el de su verificación por la parte que afirme los hechos, por lo que no considera la ley la posibilidad de que sea la parte contraria la que se encuentra en mejores condiciones de hacerlo. Obvia el legislador que la prueba presentada al proceso reviste importancia para ambos contendientes, por lo que supeditar la carga probatoria a los intereses procesales de parte constituye un desacierto; máxime cuando no regula la ley alguna fórmula que atenúe el rigor técnico de la regla en cuestión, como la inversión de la carga de la prueba o las más recientes cargas probatorias dinámicas.

Por iniciativa probatoria del juzgador, según el Diccionario Panhispánico del Español Jurídico, se entiende la facultad de la judicatura para acordar, de oficio, algunos medios de prueba $^{39}$. No obstante, la doctrina no es unánime en cuanto al alcance de la iniciativa probatoria del tribunal, que puede ser mayor o menor en dependencia de la posición que se adopte. Sin embargo, se prefiere la definición planteada, en tanto el recibimiento a prueba, la admisión o denegación y la valoración de los medios probatorios constituyen ciertamente poderes-deberes del juez, mas no comportan su intromisión en el orden material, como sí lo hace la prueba de oficio.

En el caso cubano, la iniciativa probatoria del juez encuentra expresión normativa en

\footnotetext{
${ }^{39}$ Cfr. entrada "iniciativa probatoria del juzgador", en Diccionario Panhispánico del Español Jurídico, Real Academia Española-Cumbre Judicial Iberoamericana-Consejo General del Poder Judicial, disponible en https://dpej.rae.es/lema/iniciativa-probatoria-del-juzgador; consultado el 20 de julio de 2020, 20:35 h.
} 
el art. 248 de la ley procesal, en cuya virtud el tribunal, en cualquier instancia, puede acordar de oficio -e incluso a solicitud de parte ${ }^{40}$ - antes de dictar sentencia y para mejor proveer, las diligencias de prueba que considere indispensable para llegar al cabal conocimiento de la verdad, en relación con las cuestiones planteadas. Disposición que otorga al tribunal la facultad de convertirse en sujeto agente de la prueba, ante la insuficiencia probatoria de las partes.

La LPCALE regula otras posibilidades de iniciativa probatoria de oficio, dispersas en su texto, siempre bajo la fórmula semántica "podrá disponer", que indica el carácter facultativo de su potencial actuación. Tal es el caso de la realización de reproducciones de documentos, cosas y lugares que sean de influencia decisiva en el proceso (art. 320), la celebración de careo, para mejor proveer, entre testigos cuyas declaraciones contradictorias sean determinantes para la resolución que haya de dictarse (art. 340), las diligencias necesarias en el acto de inspección de obra nueva (art. 417), las diligencias de prueba para resolver sobre la admisión de la audiencia en rebeldía (art. 446, segundo párrafo), las medidas para confirmar el estado de incapacidad de una persona, una vez visto el informe médico de rigor (art. 588, segundo párrafo) y las diligencias de prueba pertinentes para la adveración de las informaciones para perpetua memoria (art. 597).

Los supuestos anteriores tienen fundamento -igualmente- en la búsqueda de la verdad material, objetivo que signa cualquier actuación del tribunal en un modelo procesal publicístico. En general, puede decirse que tales posibilidades se incluyen en la actividad probatoria de oficio, ya que es el tribunal quien las realiza en función de un objetivo superior, como es alcanzar la justicia. Sin embargo, es la oportunidad para disponer la práctica de una prueba para mejor proveer, la que se ajusta a una real iniciativa probatoria del tribunal en el proceso civil cubano.

Otros supuestos integran lo que se conoce como actividad esclarecedora de los hechos, pero no comportan una actividad a muto propio del juzgador. Por ejemplo, la facultad de hacer comparecer a las partes en cualquier estado del proceso para interrogarlas sobre los hechos y realizar la inspección de libros o cosas que integren el material fáctico de la litis, siempre que ello propicie un mejor conocimiento de los hechos, de conformidad con el art. 42 de la LPCALE. Prerrogativa que, si bien tiene cierto matiz probatorio, no implica la

\footnotetext{
${ }^{40}$ En cuyo caso no existe iniciativa probatoria del tribunal, sino de parte.
} 
práctica de medios de prueba, sino la indagación y esclarecimiento de algunos extremos en particular. Como se aprecia, este poder puede ejercerse en cualquier momento procesal, pero no ha sido utilizado con frecuencia por la judicatura patria.

Cuestión diferente es la contenida en el art. 45 de la ley rituaria, que en franca regulación del principio de oficialidad establece la facultad del tribunal para resolver sobre aspectos no contenidos en los pedimentos iniciales de las partes, siempre que guarden relación con ellos y se instruya a las mismas para que hagan sus alegaciones y propongan las pruebas que estimen convenientes en defensa de su derecho. Nótese que se trata de una facultad extraordinaria, que le permite saltarse la congruencia cuando no tiene claridad sobre lo planteado y debatido en juicio, producto de la presencia de nuevos elementos que requieren el despliegue de mayor actividad procesal. Constituye un poder instructorio, que pone a las partes en conocimiento de nuevos aspectos sobre los que el juzgador necesita escuchar sus particulares apreciaciones y, en consecuencia, también requieren su prueba. Pero ello no se traduce en iniciativa probatoria de las partes, porque no son ellas las que introducen los hechos nuevos al proceso, sino el tribunal, a partir de lo debatido en las actuaciones. Tampoco se trata de iniciativa probatoria del tribunal, sino de un poder que surge de la aparición de indicios, o cuando de las pruebas practicadas surgen nuevos hechos, o por la presencia de hechos accesorios, requeridos todos de alegaciones y prueba. Ahora bien, si estos nuevos hechos no son suficientemente probados por las partes, el tribunal entonces puede disponer la práctica de los medios probatorios necesario, por vía de la institución del mejor proveer.

La ratio legis de este último precepto se encuentra en los procesos de corte no dispositivo, fundamentalmente los familiares, pues los intereses superiores que a estos conflictos subyacen ofrecen un abanico más amplio de posibilidades al juzgador en lo concerniente al sustrato material de la litis. No obstante, pudiere resultar de aplicación en los procesos puramente civiles, si la situación fáctica lo requiere; sobre todo a partir de la entrada en vigor del nuevo Código de Procesos, que acentúa el carácter público del proceso civil cubano ${ }^{41}$.

\footnotetext{
${ }^{41}$ Por ejemplo, en un conflicto sobre relaciones de vecindad que, aunque tenga por objeto un pedimento concreto, amerite el referido salto a la congruencia, producto de nuevas circunstancias surgidas del desarrollo de la actividad procesal. Conflicto típicamente civil, pero que puede traer a colación la aparición de nuevas circunstancias que afecten la realidad circundante y, derivado de ello, se precise una mayor intervención del tribunal.
} 


\subsection{Las pruebas para mejor proveer}

Con MANTECón RAMOS, se sostiene que "a través del mejor proveer puede demarcarse didácticamente la fisonomía de la prueba de oficio" ${ }^{\circ 2}$, por supuesto, en los contornos del proceso civil cubano. No cuenta el juez cubano, por lógicas razones ${ }^{43}$, con un art. como el 429 de la LEC española de 2000, que ubicado en el momento de la audiencia preliminar, faculta al juez para, respetando los límites del principio dispositivo y las fuentes de prueba obrantes en actuaciones, y ante la insuficiencia probatoria de las partes, disponer la práctica de medios de prueba que la completen ${ }^{44}$.

Según la regulación del art. 248 de la LPCALE, las pruebas para mejor proveer pueden practicarse en cualquier instancia, por lo que procede también en el segundo nivel de conocimiento, correspondiente a la apelación. A su vez, constituyen diligencias genéricas, por lo que abarcan a todos los medios probatorios regulados en la ley, sin restricción; al tiempo que constituyen complemento de la actividad desarrollada por las partes en la fase de prueba, de ahí su naturaleza subsidiaria o residual.

$\mathrm{Su}$ objeto estriba en la búsqueda de la verdad material, entendida como la verdad extraprocesal; que también se erige como objetivo teleológico de la prueba en general; cuestión que encuentra no pocos críticos en la doctrina. En definitiva, si la finalidad mediata del proceso civil es alcanzar la justicia, tiene sentido entonces que el juez, en el ejercicio de la impartición de justicia, pueda acercarse, a partir de su propia actividad, a la verdad. Sin embargo, encuentran límite en los hechos introducidos por las partes, o por el tribunal, con respeto de las reglas del art. 45 de la LPCALE, o sea, cuando la prueba de oficio guarde relación con las cuestiones planteadas y debatidas en el proceso. Ahora bien, que las partes

\footnotetext{
${ }^{42}$ MANTeCón RAmos, A., "Introducción...", ob. cit., p. 39. De este mismo autor, con mayor profundidad, vid. Cien problemas de la prueba judicial en lo civil, Ediciones ONBC, La Habana, 2014, pp. 132-145.

${ }^{43}$ Primero, porque no se estructura a través de la celebración de audiencias sucesivas y, segundo, porque en la comparecencia que presenta rasgos similares a los de una audiencia preliminar, no se incluye la posibilidad de prueba, ni para las partes ni para el tribunal, tan solo la fijación de los hechos y la eventual apertura de la fase probatoria.

${ }^{44}$ Un análisis exhaustivo del art. 429 de la LEC española de 2000 se encuentra en MARRERO FRANCÉs, I., MARTínez SÁnchez, M., Rodríguez AnTúNEZ, D. y M. De Ros SAMPEDRo, "Análisis art. 429.I, II y III de la LEC", en Abel Lluch, X. y J. PICó I Junoy (Coords.), Los Poderes del Juez Civil en Materia Probatoria, Ed. J. Ma Bosch editor, Barcelona, 2003, pp. 41-66. Con visión práctica, vid. ABel LluCH, X. y J. PICó I JUNOY, "La iniciativa probatoria del juez civil. A propósito de un caso", en ABEL LLUCH, X. y J. PICó I JUNOY (Coords.), Los Poderes del Juez Civil..., ob. cit., pp. 137-174.
} 
no hayan intentado la demostración de alguno de los hechos objeto de prueba, no significa que el tribunal no pueda hacerlo por vía del mejor, pues el límite se encuentra en que sea un hecho contenido en actuaciones ${ }^{45}$.

Como nota distintiva de su regulación, cabe acotar que, si bien pueden ser solicitadas por las partes, ello no significa que la institución está destinada a suplir la inactividad de aquellas respecto a un hecho concreto; o sea, que este mecanismo no está diseñado para probar lo que debe probarse en la fase de pruebas ${ }^{46}$. Asimismo, la solicitud de estas diligencias por las partes se circunscribe a lo regulado en los apartados tercero y cuarto del art. 623 de la LPCALE, o sea, cuando después de la oportunidad legal para proponer prueba, hubiere ocurrido algún hecho nuevo de influencia en el proceso, que aun siendo anterior, la parte a quien interese asegure, bajo la responsabilidad correspondiente al delito de perjurio, no haber tenido antes conocimiento de aquel; o cuando el demandado declarado rebelde no citado en su persona, haya comparecido después de la oportunidad legal para proponer pruebas.

Respecto al momento procesal de su práctica, como su naturaleza es residual, obvio resulta que se lleve a cabo una vez declarado el proceso concluso para dictar sentencia y antes del dictado de la misma, o mejor, antes que se lleve a cabo la votación del fallo, como bien indica MANTECón RAMOS ${ }^{47}$. Para ello, cuenta el tribunal con el plazo de ocho días, que por ser impropio, puede ser extendido, sin que ello implique una fractura de la celeridad que el dictado de la sentencia requiere, en un plazo razonable.

Sobre la crítica a las pruebas para mejor proveer, en el orden doctrinal, no se abunda en esta ocasión. De acuerdo con PICÓ I JUNOY, en juicio propio, la prueba de oficio no resulta incompatible con la iniciativa probatoria de las $\operatorname{partes}^{48}$, sino que conviven armónicamente, ya que lo verdaderamente arbitrario sería el monopolio exclusivo del juez sobre la actividad probatoria. Tampoco constituyen óbice los intereses privados de las partes en el resultado

\footnotetext{
${ }^{45}$ Cfr. SSTSP núm. 1342/2001, de 21 de noviembre, recurso de casación en materia administrativa radicado en el expediente núm. 860/2001, y núm. 396/2010, de 27 de diciembre, recurso de casación en materia civil radicado en el expediente núm. 400/2010.

${ }^{46}$ Cfr. SSTSP núm. 971/2001, de 24 de julio, recurso de casación en materia administrativa radicado en el expediente núm. 545/2001, y núm. 1047/2006, de 26 de diciembre, recurso de casación en materia administrativa radicado en el expediente núm. 2168/2006.

${ }^{47}$ MANTECón Ramos, A., Cien problemas..., ob. cit., p. 144.

${ }^{48}$ Picó I JunOY, J., El juez y la prueba. Estudio de la errónea recepción del brocardo iudex iudicare debet secundum allegata et rpobata, non secundum conscientiam y su recepción actual, Ed. J. $\mathrm{M}^{\mathrm{a}}$ Bosch editor, Barcelona, 2007, pp. 104-117.
} 
del proceso, pues nada impide que el juez vele por la realización de tales intereses y, al mismo tiempo, por la justicia. Por supuesto, la prueba de oficio no rompe con la carga de la prueba, institución que cobra sentido al momento de dictar sentencia y, por tanto, el juez puede, en momento anterior, ordenar la práctica de las pruebas que considere necesarias para arribar a un fallo justo. Por último, no es cierto que la prueba de oficio conculque la imparcialidad del juzgador, ya que con ello no adelanta su fallo, no prejuzga, sino que encuentra la solución efectiva ante la duda razonable que le produce la ineficiente labor de probanza desplegada por las partes. Claro está, el juez debe, en todo momento, velar por la estricta configuración del contradictorio y el mantenimiento de la igualdad procesal, pues otra cosa redunda en perjuicio de los querellantes.

\section{El modelo de juez civil cubano del futuro y sus potestades en materia de prueba}

La Constitución de la República de Cuba de 2019, al regular las garantías relativas a la tutela judicial efectiva y el debido proceso, obliga -no solo por contener un mandato expreso al respecto- a una reforma integral del proceso civil cubano, que ahora debe mirar a la oralidad como principio guía del procedimiento y, a su tenor, debe ser estructurado en las sucesivas audiencias preliminar, probatoria y conclusiva o de cierre; al tiempo que debe contener en su parte general los principios procesales que sirven de sostén a todos los tipos procesales y las herramientas -de parte y del tribunal- útiles a todos ellos, como son las medidas cautelares, la prueba, los medios de impugnación y la ejecución de sentencias.

El anteproyecto de Código de Procesos que debe debatirse y aprobarse a finales de 2020 en el parlamento cubano, contiene por primera vez un catálogo de principios que irradian a todos los tipos procesales, que van desde el acceso a la justicia y el derecho a la defensa, pasando por el respeto de los valores constitucionales y la observancia de las garantías procesales por el tribunal, hasta los relativos a algunos tipos procesales en concreto, como los que cobijan los derechos de las personas en situación de vulnerabilidad o los relativos a la familia y los derechos laborales.

Por supuesto, esta inminente reforma de los procesos no penales en Cuba requiere un nuevo tipo de juez que, si bien respeta la legalidad y encuentra en la Constitución y las leyes su fuente primaria de actuación, no permanezca pasivo en la dirección formal y material del 
proceso. Por supuesto, si el nuevo Código se monta en los cánones del proceso civil moderno, el juez debe implementarlo a través de su papel activo, acompañante de los derechos e intereses legítimos de las partes, pero sobre todo de la justicia en el caso concreto.

En materia de prueba se revelan varias cuestiones relevantes, que se aprecian desde la misma regulación de los principios procesales que rigen el anteproyecto de ley. En primer lugar, el art. 6 establece que, sin perjuicio de las atribuciones reservadas a las partes, los tribunales mantienen una posición activa en los procesos, con el propósito de lograr una plena certeza sobre lo que se litiga. Por tanto, la actividad pasiva del juzgador contradice la esencia misma de la efectividad de la tutela judicial reclamada y del debido proceso, y siendo el legislador consciente de ello, una actividad contraria puede colocar en indefensión a los justiciables.

Pero nótese que no establece este principio a la búsqueda de la verdad como objetivo de la actividad jurisdiccional, sino el logro de certeza respecto a lo litigado, que aunque le cataloga de plena y le imprime con ello cierto matiz subjetivo, conoce el legislador que la verdad material resulta de difícil verificación en el campo de los procesos dispositivos. Respecto a la valoración de las pruebas, rompe este cuerpo legal con el criterio mixto todavía vigente, otorgándole plena libertad al juez en su apreciación, pero ajustado a los criterios de la racionalidad y de la lógica, de conformidad con lo establecido en el art. 13, que encuentra expresión en un poder concreto contenido en el apartado segundo del art. 60, incluido en el capítulo correspondiente a las facultades y potestades del tribunal.

Se mantiene, prácticamente con la misma redacción, el contenido de los actuales arts. 42 y 45 de la LPCALE, ahora en los arts. 59 y 61 del anteproyecto, relativos a la citación de las partes para interrogarles sobre los hechos y la inspección de libros o cosas que tribute a su esclarecimiento, y la posibilidad de introducir nuevos elementos relacionados a los pedimentos de parte, requeridos de alegaciones y prueba.

Pero lo verdaderamente novedoso en materia de poderes probatorios del juez se ordena en el art. 301, contenido en las disposiciones generales de la prueba y que establece la prueba de oficio, a practicarse por el tribunal en cualquier estado del proceso, siempre que las considere necesarias para el esclarecimiento de los hechos. De esta regulación se desprenden cuatro cuestiones esenciales: la primera, su alcance general, ya que incluye a todos los medios de prueba regulados en la ley y rige para todos los procesos y niveles de 
conocimiento; la segunda, que no existe límite temporal para su práctica, pues su objeto es arribar a certeza sobre los hechos, y ello debe ocurrir siempre que el tribunal albergue dudas sobre los mismos; la tercera, el legislador comprende la iniciativa probatoria del tribunal dentro de la actividad de esclarecimiento de los hechos, acorde con la doctrina contemporánea; y por último, que excluye la necesidad de diligencias finales o para mejor proveer, en virtud de su amplitud temporal. La regulación propuesta indica que el diseño procesal está basado en la oralidad, por lo que el tribunal puede ejercitar este poder desde la misma audiencia preliminar, debido a que los medios de prueba han sido propuestos en los escritos polémicos, de ahí que puedan ventilarse en el acto oral que inicia los debates judiciales.

En otro orden de cosas, resulta verdaderamente revolucionario la inclusión, en el art. 302, apartados primero y segundo, que el tribunal de oficio o a petición de parte, puede atribuir la carga de la prueba de determinado hecho a la parte que se encuentre en una posición más favorable para demostrarlo, cuando sea notoria su cercanía o relación directa con las evidencias que permiten su verificación. Regulación que se corresponde con las doctrinalmente denominadas cargas probatorias dinámicas.

Por tanto, ya existen las bases legales del nuevo proceso y su modelo de juez, acorde con las máximas constitucionales de rigor. Resta su aprobación parlamentaria y sobre todo impregnar el nuevo espíritu en los jueces que dirigen la vida procesal del país, quienes tienen inoculado el modelo procesal vigente. Cambiar la mente de los jueces es, entonces, el reto mayor.

\section{A guisa de cierre}

Los poderes del juez en el proceso civil cubano, aunque responden a una dinámica procesal incongruente con lo que se considera el moderno proceso civil, posibilitan la actuación del tribunal en su camino hacia la justicia. No obstante, ello no se verifica en la práctica, a pesar de los enconados esfuerzos del CGTSP, lo que refuerza el criterio de que la base ideológica que subyace al modelo procesal, y el diseño mismo, están divorciadas.

En materia probatoria, aunque no son pocas las oportunidades del juzgador para, de oficio, acercarse a la verdad, son las pruebas para mejor proveer las que mejor se ajustan a su iniciativa probatoria, ya que lo hacen con carácter general. El resto de sus posibilidades se concretan en cierta intervención al momento de la práctica de los específicos medios de 
prueba regulados en la ley y las que tienen por cometido el esclarecimiento de los hechos, pero que no implican la ordenación oficiosa de la prueba.

El anteproyecto de Código de Procesos, de aprobarse, cambiaría sustancialmente este panorama, al regular con amplitud -objetiva y temporal- la prueba de oficio, lo que convierte al juez cubano del futuro en potencial garante de la tutela judicial efectiva. Queda entonces el anhelo de una impartición de justicia eficaz y transparente, que ahora casi se puede tocar con las manos.

\section{REFERENCIAS}

Alcalá-Zamora y CAStillo, N. "La influencia de Wach y Klein sobre Chiovenda”, en Revista de Derecho Procesal, Buenos Aires.

Alcalá-Zamora y Castillo, N. Estudios de Teoría General e Historia del Proceso (19451972), Tomo II: Números 12-30, Ed. Universidad Nacional Autónoma de México, México D.F.

Alvarado Velloso, A. Garantismo procesal contra actuación judicial de oficio, Ed. Tirant lo Blanch, Valencia.

Álvarez Tabío, F. "El juez activo en el proceso civil”, en A.A.V.V., Anuario de la Asociación Nacional de Funcionarios del Poder Judicial, Curso de Conferencias sobre Derecho Procesal, Ed. Lex, La Habana.

Berizonce, R., "Ideologías y proceso”, en MEndoza DíAZ, J., "El Derecho Procesal y los retos de la contemporaneidad", Ed. Universidad Católica de Santiago de Gauayaquil, Santiago de Guayaquil.

Calamandrei, P. Demasiados abogados, Biblioteca de la Revista de Derecho Privado, Serie A-I, Librería de Victoriano Suárez, Madrid.

Calamandrei, P. Instituciones de Derecho Procesal Civil. Según el nuevo Código, Vol. I, traducción de la segunda edición italiana y estudio preliminar por Santiago Sentís Melendo, Ediciones Jurídicas Europa-América, Buenos Aires.

Chico FERnÁNDEZ, T. "La carga de la prueba y la iniciativa probatoria de oficio en la LEC", en Abel Lluch, X. y J. Picó I Junoy (Dirs.), Objeto y carga de la Prueba Civil, Ed. J. Ma Bosch editor, Barcelona. 
CIPRIANI, F. “Ideología de la función judicial. En el centenario de Klein”, en Revista de Instituto Colombiano de Derecho Procesal, Vol. 27, Bogotá.

CIPRIANI, F. "El proceso civil italiano entre eficiencia y garantías, en CIPRIANI, F., Batallas por la justicia civil - Ensayos, traducción de Eugenia Ariano Dehu, Ed. Cultural Cuzco, Lima.

Couture, E. Estudios de Derecho Procesal Civil, Tomo I, Ediar Editores, Buenos Aires.

De Montagú, G. Origen y formación del proceso civil moderno, Ed. Cultural S.A., La Habana.

GONZÁLEZ ÁlVAREZ, R. "Eficientismo y garantismo procesales en serio: pasando la página del debate entre publicismo y dispositivismo procesales", en Derecho y Sociedad, núm. 38.

Grandi, D. "La Relación Grandi”, en De Cellis, F. y J. DASSEn (Trads.), Código de Procedimiento Civil italiano. Exposición de motivos, Ed. Depalma, Buenos Aires.

Gurvich, M. A. "Objeto y sistema de la ciencia del Derecho Procesal Civil Soviético", en Gurvich, M. A. (Dir.), Derecho Procesal Civil Soviético, traducción de Miguel LubÁN, Ed. Instituto de Investigaciones Jurídicas de la Universidad Nacional Autónoma de México, México D.F.

MANTECón RAmOs, A Cien problemas de la prueba judicial en lo civil, Ediciones ONBC, La Habana.

MANTECón RAMOS, A. "Teoría general de la prueba en el proceso civil”, en PÉREZ Gutiérrez, I. (Coord.), Derecho Procesal Civil, Ed. Félix Varela, La Habana, 2016.

Mantecón RAmos, A. Introducción al Derecho Probatorio, Ediciones ONBC, La Habana. Marrero Francés, I., Martínez SÁnchez, M., Rodríguez Antúnez, D. y M. De Ros SAMPEDRO “Análisis art. 429.I, II y III de la LEC”, en ABEL LLuCh, X. y J. Picó I Junoy (Coords.), Los Poderes del Juez Civil en Materia Probatoria, Ed. J. M ${ }^{\mathrm{a}}$ Bosch editor, Barcelona.

Masciotra, M. Poderes-deberes del juez en el proceso civil, Ed. Astrea, Buenos AiresBogotá.

Masciotra, M. "Lineamientos del proceso civil", en El Derecho. Diario de Doctrina y Jurisprudencia, edit. Universidad Católica Argentina, núm. 14057, Año LIV. 
Mendoza DíAz, J. "Un acercamiento al Proceso Civil cubano", en Mendoza DíAz, J.

(Coord.), Panorama del Derecho Procesal Hispanocubano, Ed. Tirant lo Blanch, Valencia.

Mendoza Díaz, J. Derecho Procesal. Parte General, Ed. Félix Varela, La Habana.

Monteleone, G. "Principios e ideologías del proceso civil: impresiones de un revisionista", en MONTERO AROCA, J. (Coord.), Proceso Civil e Ideología. Un prefacio, una sentencia, dos cartas y quince ensayos, $2^{\mathrm{a}}$ edición, Ed. Tirant lo Blanch, Valencia.

Montero Aroca, J. Los principios políticos de la nueva Ley de Enjuiciamiento Civil. Los poderes del juez y la oralidad, Ed. Tirant lo Blanch, Valencia.

MONTERO AROCA, J. Proceso Civil e Ideología. Un prefacio, una sentencia, dos cartas y quince ensayos, $2^{\mathrm{a}}$ edición, Ed. Tirant lo Blanch, Valencia.

PiCó I JunOY, J. El juez y la prueba. Estudio de la errónea recepción del brocardo iudex iudicare debet secundum allegata et rpobata, non secundum conscientiam y su recepción actual, Ed. J. $\mathrm{M}^{\mathrm{a}}$ Bosch editor, Barcelona.

PiCó I JunOY, J. "El Derecho Procesal entre el garantismo y la eficacia: un debate mal planteado", en Derecho y Sociedad, núm. 38, 2012.

PiCó I JUNOY, J. “Ideología y proceso... In medio virtus”, en Justicia. Revista de Derecho Procesal, núm. 2, 2016.

TARUfFo, M. Páginas sobre justicia civil, traducción de Maximiliano Aramburo Calle, edit. Marcial Pons, Madrid.

TARUFFO, M. "Ideologías y teorías de la justicia civil”, en RAMíREZ CARVAJAL, Diana (Coord.), Proceso judicial y cultura. Una mirada global, Ed. Universidad de Medellín, Medellín. 